\title{
Implementasi Penatausahaan Hasil Hutan Hak di Kabupaten Polewali Mandar Sulawesi Barat
}

\author{
Andi Arafat ${ }^{1, *}$, Yusran Yusran ${ }^{2}$, Mas'ud Junus $^{2}$, dan Adrayanti Sabar ${ }^{2}$ \\ ${ }^{1}$ Staf Pengajar Fakultas Pertanian dan Kehutanan Universitas Sulawesi Barat \\ ${ }^{2}$ Staf Pengajar Fakultas Kehutanan Universitas Hasanuddin \\ *E-mail: andi.arafat@yahoo.com
}

\begin{abstract}
Position forest rights as one of the supporting timber availability in the industry can not be separated from the challenges and dynamics of forest product administration. It required a review of management of forest products from the forest rights in its implementation. This study aims to analyze the implementation of the rights of forest product administration in Polewali Mandar, using descriptive analysis with the existing indicators on variables and dimensions were obtained in accordance with the guidelines for the interview. The results of analysis tools provide the opportunity regulatory administration of forest products to the widest public / private forest owners as well as the adjustment of government policy related to the field of forestry sustainable forest management (SFM) and Timber Legality Verification (VLK). Implementation of the regulatory activities in the form of socialization only held one and the absence of formal socialization to the new set of rules; Issuing Certificates of Origin (SKAU) wood as much as 33 (thirty-three) of 144 (one hundred and forty-four) villages, yet the publisher SKAU set by BP2HP; SKAU publishing process by following the same line district offices are not in line with existing regulations and create problems in terms of time, cost and control; The lack of reporting of forest production and recapitulation SKAU Publisher SKAU to the district forestry department reporting that impact the realization of the production and distribution of forest products are not going well right. Implementation of the management of forest products in Polewali Mandar rights do not go according to Forestry Minister Regulation No. P.30 / Menhut-II / 2012 are rearranged in the Minister of Environment and Forestry No. P.21 / MenLHK-II / 2015 on the administration of forest products of forest rights;
\end{abstract}

Keywords: implementation; administration; forest rights; legal aspects; SKAU.

\section{PENDAHULUAN}

Undang-Undang Nomor 41 Tahun 1999 pasal 1 huruf (e) menyatakan hutan hak adalah hutan yang berada pada tanah yang dibebani hak atas tanah dan pasal 36 angka (1) Pemanfaatan hutan hak dilakukan oleh pemegang hak atas tanah yang bersangkutan, sesuai dengan fungsinya. Hutan hak yang didefinisikan sebagai hutan yang berada pada tanah yang dibebani hak atas tanah yang bisa dikaitkan dengan istilah tersebut adalah hutan rakyat. Hutan rakyat harus dimaknai dengan mempertimbangkan kondisi dan pengetahuan lokal. Tidak ada definisi tunggal terhadap pemahaman tentang hutan rakyat (Suprapto, 2010).

Peran hutan rakyat yang menghidupi masyarakat telah memberi kontribusi ekonomi nyata pada masa sekarang dan masa depan (Utari, 2012) Oleh karena itu sangat penting untuk membangun atau mendorong perkembangan hutan rakyat, khususnya yang dikelola secara individual (Simon, 2010). Tiga hal terkait hutan rakyat yaitu keunggulan sistem hutan rakyat, tantangan pengembangan hutan rakyat dan tindakan apa yang perlu didorong untuk mendukung eksistensi hutan rakyat. Hal pertama bahwa hutan rakyat yang telah berkembang dan dikembangkan oleh masyarakat mempunyai keunggulan dalam beberapa hal hutan rakyat terbukti mampu mendukung perekonomian pedesaan dan dapat dijadikan sebagai katup penyelemat ekonomi masyarakat pada saat krisis sekalipun. Walaupun pada awalnya berupa program pemerintah, pengembangan hutan rakyat dipengaruhi oleh kesungguhan masyarakat untuk merehabilitasi lingkungan dan lahan pertanian miliknya. Terbangunnya pasar kayu rakyat juga menjadi insentif yang penting yang mendorong masyarakat untuk tetap melestarikan hutan rakyat. Kedua, hutan rakyat merupakan solusi bagi permasalahan lingkungan dan ketiga bahwa beberapa hal yang perlu dikembangkan untuk mendukung 
eksitensi hutan rakyat melalui perlunya mengintegrasikan keberadaan hutan rakyat dalam rencana pembangunan dan pengembangan wilayah (Suprapto, 2010).

Peran pemerintah dalam bidang kehutanan adalah sebagai pembuat kebijakan dalam sistem regulasi untuk pedoman dalam pengelolaan hutan, baik dalam bentuk rencana serta perlindungan dalam pengelolaan kehutanan. Pemerintah pusat yang dalam hal ini diwakili oleh Kementerian Kehutanan harus menjalankan fungsi tersebut agar bisa dijalankan di daerah. Pemerintah daerah juga harus mendukung kebijakan dari pusat dengan disesuaikan dengan kondisi dan karakteristik yang ada di daerah (Akhadi, 2013). Lletak hutan rakyat berdekatan/berbatasan dengan kawasan hutan negara. Peraturan atau kebijakan yang efisien dan bisa melindungi hak-hak petani secara berkeadilan sangat dibutuhkan. Regulasi yang kondusif bisa lebih diartikan pada aspek aplikasi di lapangan. Pada saat ini masih terjadi praktek pelaksanaan peraturan di lapangan yang sangat beragam. Kondisi masyarakat yang lemah pada aspek pendidikan memberi kontribusi pada lemahnya aspek penguasaan informasi, termasuk dalam hal pengetahuan terhadap peraturan yang bisa diterapkan pada penatausahaan kayu. Pada sisi lain, masih cukup banyak aparat terkait, terutama yang ada di lapangan, belum memahami secara benar tentang jenis, perkembangan dan penerapan peraturan sesuai dengan kasusnya. Kedua kondisi tersebut menjadi "celah" bagi pihak-pihak yang mempunyai kepentingan tertentu untuk mengambil keuntungan (Diniyati \& Awang, 2010).

Tingginya tingkat ilegalitas kegiatan pembalakan dan pengolahan terjadi karena sejumlah faktor. Beberapa di antaranya terkait dengan kurangnya pengetahuan mengenai prosedur resmi untuk pendaftaran usaha. Namun, pada umumnya, usaha skala kecil ilegal berkembang karena tingginya kebutuhan kayu dan terbatasnya pasokan kayu legal. Tingginya ilegalitas ini tidak serta merta menjadi pertanda ketidakpatuhan atau kesengajaan industri kayu skala kecil dalam melanggar ketentuan peraturan. Hal ini bisa terjadi karena terbatasnya pemahaman mengenai persyaratan untuk mendaftarkan usaha mereka dan ketidakpahaman terhadap prosedur yang harus diikuti. Dalam beberapa kasus, pelaku usaha sengaja melanggar hukum untuk menghindari beban pajak dan berbagai tanggung jawab administratif lainnya (Obidzinski dkk., 2015). Tidaklah terlalu salah jika dikatakan bahwa implementasi merupakan aspek yang sangat penting dalam keseluruhan proses kebijakan. Oleh karena dalam studi kebijakan publik, implementasi bukanlah sekedar bersangkut-paut dengan mekanisme penjabaran keputusan-keputusan politik kedalam prosedur-prosedur rutin melalui saluran-saluran birokrasi, melainkan lebih dari itu implementasi menyangkut masalah konflik, keputusan dan siapa yang memperoleh apa dari suatu kebijakan (Syarief, 2012). Implementasi merupakan proses umum tindakan administratif yang dapat diteliti pada tingkat program tertentu (Akib, 2010).

Posisi hutan hak sebagai sebuah proses kebijakan dalam pembangunan, pengelolaan hutan tidak terlepas dari tantangan dan dinamika penatausahaan hasil hutan. Untuk itu penelitian ini bertujuan menganalisis implementasi penatausahaan hasil hutan dari hutan hak di Kabupaten Polewali Mandar.

\section{METODE PENELITIAN}

Penelitian ini dilaksanakan di Kabupaten Polewali Mandar, Provinsi Sulawesi Barat dan pada bulan Mei sampai Agustus 2016.

\subsection{Pengumpulan Data}

Data diperoleh dari informan dipilih dengan teknik purposive, yaitu individu yang dipertimbangkan secara cermat (intuisi) dan kelompok terbaik yang dinilai akan memberikan informasi yang cukup melalui wawancara secara mendalam yang berkaitan dengan permasalahan. Selain itu dilakukan observasi dan studi dokumentasi, data-data berupa dokumen peraturan, laporan pelaksanaan, arsip lain yang relevan dengan penelitian. Studi dokumentasi dimaksudkan untuk menghimpun sebanyak mungkin pengetahuan sesuai dengan permasalahan penelitian dan bertujuan untuk mengoptimalkan kerangka teori dalam menentukan arah, konsep dan pembahasan penelitian serta menjelaskan kedudukan masalah dalam konteks yang sesuai. 


\subsection{Analisis Data}

Pengabsahan data menggunakan triangulasi data, teknik pemeriksaan keabsahan data memanfaatkan sumber yang lain di luar data tersebut untuk keperluan pengecekan atau sebagai pembanding terhadap data yang sudah ada. Secara terperinci analisis data dilakukan dengan menganalisis perangkat peraturan yang ada, digunakan metode analisis isi (content analysis), mengkaji tiap peraturan pasal perpasal. Selanjutnya data hasil wawancara dan pengamatan kemudian direduksi, dirangkum, dan dipilah-pilah hal yang pokok, difokuskan untuk dipilih (melalui proses penyuntingan, pemberian kode dan pentabelan) dan diklasifikasikan berdasarkan variabel, dimensi dan indikator faktor-faktor yang mempengaruhi implementasi penatausahaan hasil hutan hak. Reduksi dan verifikasi data dilakukan secara terus menerus sepanjang proses penelitian, proses analisis dan mencari makna dari data yang dikumpulkan (pencarian pola tema, hubungan persamaan, hipotesis) selanjutnya dituangkan dalam bentuk kesimpulan yang masih bersifat tentatif. Pandanganpandangan tertentu terhadap implementasi penatausahaan hasil hutan, dokumen kebijakan, dan hubungan antara data dengan fenomena dilapangan yang berkaitan dengan masalah yang diteliti akan terus berinteraksi sampai didapat suatu kesimpulan yang benar.

\section{HASIL DAN PEMBAHASAN}

\subsection{Perangkat Peraturan}

Penelitian ini berfokus pada pengimplementasian dasar hukum Peraturan Menteri Kehutanan Nomor P.30/Menhut-I//20012 yang kemudian diatur ulang dalam Peraturan Menteri Lingkungan Hidup dan Kehutanan Nomor P.21/MenLHK-II/2015 tentang penatausahaan hasil hutan yang berasal dari hutan hak. Perbedaan isi dari kedua peraturan menteri tersebut secara umum masih tetap memberikan keterlibatan masyarakat dan kepala desa/lurah (sebagai penerbit SKAU) dalam penatausahaan hasil hutannya

\subsection{Sosialisasi Peraturan}

Sosialisasi yang dilakukan oleh Dinas Kehutanan dan Perkebunan Kabupaten Polewali Mandar secara formal hanya terjadi 1 (satu) kali sampai berlakunya Peraturan Menteri Lingkungan Hidup dan Kehutanan Nomor P.21/MenLHK-II/2015 dalam rangkaian pembekalan pengukuran dan pengenalan jenis kayu kepada beberapa kepala desa yang diundang. Selebihnya, sosialisasi ditekankan melalui pendekatan personal (informal) yang diharapkan dilakukan oleh pegawai dan polisi kehutanan saat berada di lapangan.

\subsection{Surat Keterangan Asal Usul (SKAU)}

Terdapat 33 (tiga puluh tiga) orang Pejabat Penerbit SKAU dari 144 (seratus empat puluh empat) desa yang ada di tetapkan oleh kepala dinas kabupaten, jumlah tersebut telah mengikuti pembekalan pengukuran dan pengenalan jenis Peraturan Menteri Kehutanan Nomor P.30/Menhut-II/2012 pasal 9 ayat (2)). Namun sejak terbitnya Peraturan Menteri Lingkungan Hidup dan Kehutanan Nomor P.21/MenLHKII/2015 dimana Penerbit SKAU ditetapkan oleh Balai diketahui belum ada. Dinas kehutanan kabupaten membuat kebijakan alur penerbitan SKAU yang tidak sejalan dengan amanat peraturan menteri terkait penatausahaan hasil hutan. Adanya survei sebelum penebangan dan tidak adanya transparansi biaya pengurusan SKAU. Hasil hutan kayu dari masyarakat yang diangkut dibawa keluar daerah namun lebih cenderung di jual kepada Tempat Penampungan Terdaftar (TPT). TPT yang ada selain sebagai tempat penampungan kayu juga menjadi industri pengolahan kayu (penggergajian kayu dan meubel).

\subsection{Pengawasan dan Pelaporan}

Penyampaian laporan produksi hasil hutan hak dan rekapitulasi penerbitan SKAU dari penerbit SKAU kepada Kepala Dinas Kabupaten tidak berjalan sebagaimana mestinya. Penyampaian laporan sejak berlakunya Peraturan Menteri Kehutanan Nomor P.30/Menhut-II/20012 tidak dilakukan oleh Penerbit SKAU. Dengan demikian pelaporan realisasi produksi dan peredaran hasil hutan hak oleh Kepala Dinas Kabupaten kepada Kepala Dinas Provinsi dengan tembusan kepada Kepala Balai juga tidak berjalan baik. Data 
pelaporan yang ada hanya diambil dari pengumpulan lembar ke-2 SKAU yang sudah dikumpulkan oleh petugas di lapangan.

\subsection{Implementasi Penatausahaan Hssil Hutan di Kabupaten Polewali Mandar}

Kebijakan penataausahaan hasil hutan tidak dapat dipisahkan dengan dasar hukum yang menjadi landasan dalam proses pelaksanaannya. Realisasi kebijakan pemerintah menempatkan hukum/aturan sebagai sarana. Hadirnya aturan hukum memberikan legitimasi bagi pelaksanaan kebijakan pemerintah dalam rangka menata masyarakat maupun mengarahkan masyarakat sesuai dengan tujuan yang dikehendaki, akhirnya pemberlakuan aturan sebagai instrumen kebijakan mempunyai arti yang penting. Pada Peraturan Menteri Kehutanan Nomor P.30/Menhut-I/20012 yang kemudian diatur ulang dalam Peraturan Menteri Lingkungan Hidup dan Kehutanan Nomor P.21/MenLHK-II/2015 tentang penatausahaan hasil hutan yang berasal dari hutan hak dari hasil analisis tiap pasal perpasal terjadi perubahan beberapa defenisi (ketentuan umum) juga terjadi perubahan pada penetapan pejabat penerbit SKAU, penggunaan nota angkutan dan SKAU, serta dihilangkannya pelaporan produksi hasil hutan hak dan rekapitulasi penerbitan SKAU oleh penerbit SKAU.

Ditetapkan dan atau berubahnya peraturan dimaksudkan untuk tercapainya tujuan suatu kebijakan yang akan mempengaruhi implementasi peraturan tersebut di lapangan. Peraturan menteri ini selain memberikan kesempatan penatausahaan hasil hutan yang seluas-luasnya kepada masyarakat/pemilik hutan hak juga terbaca sebagai bentuk penyesuaian atas Undang-Undang Nomor 23 Tahun 2014 dan kebijakan pemerintah bidang kehutanan terkait penilaian kinerja pengelolaan hutan produksi lestari (PHPL) dan verifikasi legalitas kayu (VLK).

Pengimplementasian penatausahaan hasil hutan di Kabupaten Polewali Mandar secara umum dapat dilihat pada gambar 1 kegiatan Penatausahaan hasil hutan Dinas Kehutanan dan Perkebunan Kabupaten Polewali Mandar Tahun 2012-2016. Salah satu bagian terpenting dari kehadiran aturan hukum adalah hadirnya sosialisasi. Sosialisasi dengan pendekatan informal lebih terlihat tepat sasaran namun dapat memberi ruang terjadinya pemahaman yang bias di masyarakat. Tingkat pengetahuan dan pemahaman yang cukup bagi pegawai dan polisi kehutanan terkait peraturan dalam mensosialisasikan sangat dibutuhkan.

Penyebarluasan informasi peraturan dari satu pihak (pemerintah) ke pihak lain (masyarakat umum) merupakan bentuk proses pemberdayaan, dimana diharapkan dapat menumbuhkan kesadaran kritis, perubahan sikap, dan perilaku masyarakat. Oleh sebab itu, sosialisasi harus terintregasi dalam aktifitas pemberdayaan dan dilakukan secara terus menerus untuk masyarakat dapat menjalankan kebijakan secara berkesinambungan sesuai aturan yang ada. Diperlukan beberapa pendekatan sosialisasi yang didasarkan atas perbedaan sasaran (kondisi masyarakat), pilihan pendekatan-pendekatan yang dilakukan, diharapkan bisa membangun keterlibatan masyarakat melalui pertukaran pengalaman, pengetahuan, dan pemahaman untuk melaksanakan peraturan yang ada.

Kejelasan tujuan dan cara yang akan digunakan dalam sebuah kebijakan merupakan hal yang mutlak agar dapat diimplementasikan sebagaimana yang telah diputuskan. Namun hal tersebut tidak selalu terjadi (Triana, 2012). Sosialisasi merupakan proses mengupayakan masyarakat luas memahami dan mampu menginternalisasikan 'makna' dari konsep dan tujuan dari kebijakan pemerintah. Masyarakat luas mengetahui dan memahami kebijakan pemerintah sebagai bagian dari pertanggungjawaban terhadap publik, menjadi bagian dari pelaksanaan aturan yang terdapat dalam siklus kebijakan pemerintah. Sedangkan secara khusus adalah komitmen dan kerjasama antara pemerintah dengan masyarakat.

Kebijakan secara nasional dapat dilaksanakan secara baik mulai dari tingkat pusat sampai kabupaten jika terdapat mekanisme dan aturan main yang jelas. Dengan demikian konsistensi kebijakan makro kehutanan mulai dari tingkat pusat dan daerah dapat terjaga. Kebijakan yang terkait dengan regulasi hendaknya dikembalikan pada tataran hukum yang lebih tinggi. Banyaknya peraturan daerah tentang kehutanan yang dicabut karena dianggap melanggar membuktikan bahwa koordinasi antara pemerintah pusat dan daerah belum berjalan (Akhadi, 2013). Tidak adanya koordinasi antara dinas kabupaten dan Balai dalam mensosialisasikan peraturan yang ada terkait Peraturan Menteri Lingkungan Hidup dan Kehutanan 
Nomor P.21/MenLHK-II/2015 dengan alasan hilangnya legitimasi dinas kehutanan kabupaten berdasar peraturan menteri tersebut dan amanat Undang-Undang Nomor 23 Tahun 2014 seharusnya tidaklah terjadi. Kondisi ini menempatkan proses penatausahaan hasil hutan hak berada dalam ketidakjelasan,Masyarakat pemilik/pengelola hutan akhirnya akan menjadi korban dari kondisi ini. Implementasi kebijakan bukanlah sekedar bersangkut-paut dengan mekanisme penjabaran keputusan-keputusan politik kedalam prosedurprosedur rutin melalui saluran-saluran birokrasi, melainkan implementasi menyangkut masalah konflik, keputusan dan siapa yang memperoleh apa dari suatu kebijakan (Syarief, 2012).

Pada proses penerbitan SKAU berdasarkan peraturan yang ada sangat jelas memberikan kewenangan yang lebih besar dan kewajiban keaktifan bagi penerbit SKAU, bagaimanapun Penerbit SKAU (Kepala Desa/Lurah atau perangkat desa/kelurahan) adalah mereka yang dianggap memahami wilayahnya. Kewenangan yang penuh kepada penerbit SKAU untuk menyelenggarakan fungsi melakukan pemeriksaan kelengkapan administrasi (kebenaran asal usul hasil hutan dan kepemilikan) yaitu dengan mengecek dan memastikan bahwa hasil hutan hak berasal dari lokasi yang benar yang dibuktikan dengan adanya alas titel/hak atas tanah dan pemeriksaan fisik (Jenis, volume/berat dan jumlah hasil hutan hak yang akan diangkut).

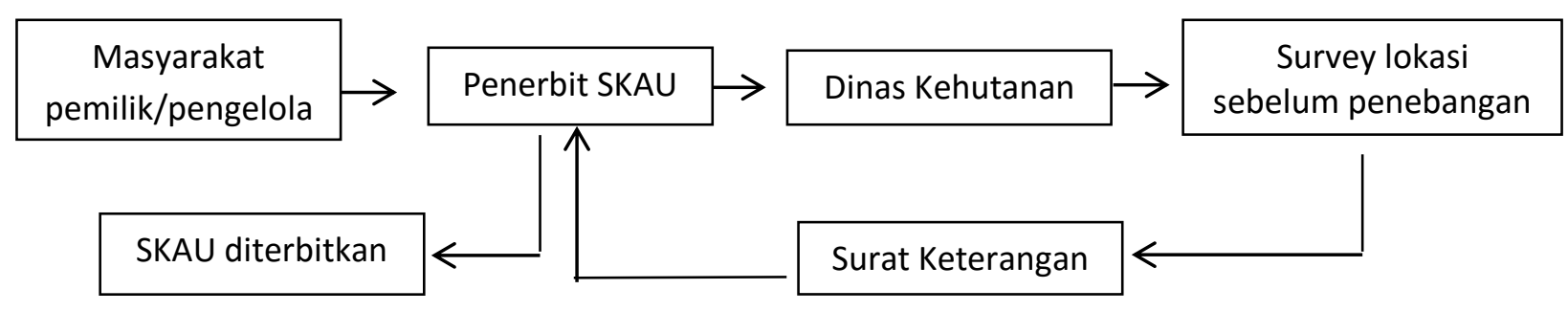

\section{Gambar 1. Alur Kebijakan Penerbitan SKAU Dinas Kehutanan Kabupaten Polewali Mandar}

Pertimbangan pencegahan penebangan kayu dari lokasi hutan negara (klaim beberapa penerbit SKAU tidak mengetahui batas kawasan hutan negara) dan dalam rangka ketertiban pelaksanaan penatausahaan hasil hutan hak sebagai bentuk kewajiban melakukan pemantauan, pengawasan dan pengendalian peredaran hasil hutan yang menjadikan dinas kehutanan kabupaten membuat kebijakan alur penerbitan SKAU adalah langkah yang baik namun hal ini tidak sejalan dengan amanat peraturan menteri terkait penatausahaan hasil hutan. Adanya survey sebelum penebangan dan tidak adanya survey pasca tebang dengan kebijakan penetapan alur yang demikian memberikan dampak hilangnya fungsi penerbit SKAU (kepala desa), tingginya biaya operasional, terbukanya pelanggaran (pemanfaatan keadaan) oleh beberapa oknum petugas kehutanan, lahirnya persepsi SKAU dibeli lahir dari tidak adanya transparansi biaya pengurusan SKAU oleh dinas kehutanan kabupaten dan secara umum akibat panjangnya alur penerbitan membuat waktu yang dibutuhkan oleh masyarakat pemilik/pengelola hutan hak mendapatkan manfaat akan begitu lama (manfaat ekonomi).

Analisis implementasi (a framework for implementation analysis) yang diperkenalkan oleh Mazmanian dan Paul A. Sabatier dalam Nugroho (2006) salah satu variabel implementasi adalah variabel intervening dimana sebuah kebijakan mampu untuk menstrukturkan proses implementasi dengan indikator kejelasan dan konsistensi tujuan. Dipergunakannya teori kausal, ketepatan alokasi sumber dana, keterpaduan hirarki di antara lembaga pelaksana, aturan dan lembaga pelaksana, serta perekrutan pejabat pelaksana. Pentingnya keterbukaan kepada pihak luar dan variabel di luar kebijakan mempengaruhi proses implementasi yang berkenaan dengan indikator kondisi sosio-ekonomi dan teknologi, dukungan publik, sikap dari konstituen, dukungan pejabat yang lebih tinggi serta komitmen dan kualitas kepemimpinan pejabat pelaksana.

Peran Penerbit SKAU yang kurang aktif melakukan pemeriksaan ditunjang dengan dasar bahwa hasil hutan telah disurvei sebelum penebangan oleh petugas kehutanan menjadikan proses pengangkutan hasil hutan mengalami banyak persoalan. Istilah "lain disurvei lain yang diangkuf" sangat tepat untuk menggambarkan beberapa kasus pelanggaran yang terjadi dalam kondisi ini. Beberapa pelanggaran yang 
sering terjadi pada proses pengangkutan hasil hutan, terjadinya perbedaan jenis, volume dan jumlah hasil hutan yang diangkut dengan yang tercantum di SKAU merupakan akumulasi dari kebijakan alur yang ditetapkan oleh dinas kabupaten yang diperkuat dengan tidak adanya Standart Operating Procedure (SOP) yang dipahami bersama.

Selanjutnya hasil hutan kayu dari masyarakat yang diangkut berdasarkan hasil pengamatan selain dibawa keluar daerah juga lebih cenderung di jual kepada Tempat Penampungan Terdaftar (TPT). TPT yang ada selain sebagai tempat penampungan kayu juga menjadi industri pengolahan kayu (penggergajian kayu dan meubel). Berdasarkan aturan, TPT yang berfungsi sebagai industri penggergajian kayu pada dasarnya tidak diperbolehkan. Larangan TPT yang juga berfungsi sebagai industri meskipun telah tertuang dalam surat keputusan penetapan TPT oleh Kepala dinas kehutanan kabupaten namun kenyataannya penertiban TPT tidak dapat berjalan sebagaimana mestinya. Kurangnya komitmen penegakan aturan ditunjang dengan tidak adanya data terkait kapasitas produksi tiap industri pengolahan kayu juga menjadi alasan yang membuat TPT yang berfungsi industri pengolahan kayu tidak dapat dipisahkan. Namun hal ini lebih terlihat sebagai bentuk pembiaran yang ada akibat tarik menarik kepentingan antara masyarakat pemilik hutan hak, penerbit SKAU, pengusaha kayu dan dinas kehutanan kabupaten dalam proses penerbitan SKAU. Saling ketergantungan yang besar, kurangnya pemahaman yang mendalam dan kesepakatan terhadap tujuan akan menempatkan implementasi tidak berjalan secara efektif (Brian W. Hoogwood dan Lewis A. Gun dalam Nugroho, 2006)

Implementasi yang efektif selain membutuhkan komunikasi yang jelas, juga membutuhkan konsistensi. Proses transmisi informasi yang baik namun dengan perintah yang tidak konsisten akan membingungkan pelaksana. Banyak hal yang bisa menyebabkan arah kebijakan menjadi tidak konsisten, diantaranya karena kebijakan memiliki beragam tujuan dan sasaran, atau kadang karena bertentangan dengan kebijakan yang lain dan banyaknya pengaruh berbagai kelompok kepentingan atas isu yang dibawa oleh kebijakan tersebut (Triana, 2012)

Tidak adanya data volume hasil produksi tiap TPT menandakan lemahnya pemahaman bersama terkait pelaporan yang seharusnya terjadi, dilain sisi administrasi penerbit SKAU yang memang tidak berjalan dengan baik menambah kompleksitas persoalan yang ada. Terkait pemberian sanksi administratif berupa pembinaan melalui teguran/peringatan tertulis diketahui cenderung tidak dilakukan oleh dinas kehutanan kabupaten. Pembinaan oleh dinas kehutanan kabupaten lebih ditekankan pada pendekatan personal yang justru mengantar pada kedekatan yang ada menjadi ruang pelemahan jalannya ketegasan aturan. Transaksi kepentingan pribadi memicu lahirnya diskriminasi perlakuan kepada para penerbit SKAU.

Dalih pencabutan ketetapan penerbit SKAU justru akan memberikan ruang tidak terkontrolnya peredaran hasil hutan hak di masyarakat menjadi kekuatan yang lebih cenderung terbaca sebagai pembelaaan dinas kehutanan kabupaten. Tidak adanya komitmen penegakan aturan yang terjadi sekali lagi dikarenakan tarik menarik kepentingan yang mewarnai kondisi yang ada. Seberapa jauh pemahaman pelaksanan terhadap kebijakan, tujuan kebijakan sangatlah penting bagi aparat pelaksana lebih-lebih apabila sistem nilai yang mempengaruhi sikapnya berbeda dengan sistem nilai pembuat kebijakan, maka implementasi kebijakan tidak akan berjalan dengan efektif. Ketidakmampuan administratif dari pelaksana kebijakan yaitu ketidakmampuan dalam menanggapi kebutuhan-kebutuhan dan harapan-harapan yang disampaikan oleh masyarakat dapat menyebabkan pelaksanaan suatu program tidak efektif (Triana, 2012).

\section{KESIMPULAN}

Pelaksanaan penatausahaan hasil hutan hak di Kabupaten Polewali Mandar tidak berjalan sesuai dengan Peraturan Menteri Kehutanan Nomor P.30/Menhut-I//2012 yang diatur ulang dalam Peraturan Menteri Lingkungan Hidup dan Kehutanan Nomor P.21/MenLHK-II/2015 tentang Penatausahaan hasil hutan dari hutan hak. Dalam pelaksanaannya, penatausahaan hasil hutan hak masih perlu dikaji dan ditunjang dengan petunjuk pelaksanaan dan petunjuk teknis agar tercapai penyelenggaraan penatausahaan hasil hutan hak yang tertib lancar dan terkendali. 


\section{DAFTAR PUSTAKA}

Akhadi A., Wijaya A. F., \& Hardjanto I. (2013). Perencanaan Pembangunan Kehutanan Daerah dalam Perspektif Good Governance. Jurnal Penelitian Kehutanan Wallacea vol. 2 no. 1,: 51 - 64.

Akib A. (2010). Implementasi Kebijakan: Apa, Mengapa, Dan Bagaimana. Jurnal Administrasi Publik, volume 1 no. $1: 1-11$.

Diniyati D \& Awang S. A. (2010). Kebijakan Penentuan Bentuk Insentif Pengembangan Hutan Rakyat Di Wilayah Gunung Sawal, Ciamis Dengan Metoda AHP. Jurnal Analisis Kebijakan Kehutanan Vol. 7 No. 2, : $129-143$.

Herlinda S., Said M., Gofar N., \& Pratama, F. (2010). Analisis dan Pengumpulan Data Kualitatif. (Online). (http://eprints.unsri.ac.id/view/year/2010.html, diakses 10 Maret 2016) Kementerian Lingkungan Hidup dan Kehutanan. Undang-Undang Nomor 41 Tahun 1999 Tentang Kehutanan. Jakarta. . Peraturan Menteri Lingkungan Hidup dan Kehutanan Nomor P. 21/MenLHK-II/2015 Tentang Penatausahaan Hasil Hutan yang Berasal Dari Hutan Hak. Jakarta.

. Peraturan Menteri Lingkungan Hidup dan Kehutanan Nomor P. 32/MenLHK-II/2015 Tentang Hutan Hak. Jakarta.

Obidzinski K., Dermawan A., Andrianto A., Komarudin H., \& Hernawan D. (2015). Verifikasi Legalitas Kayu di Indonesia dan Usaha Kehutanan Skala Kecil Pelajaran dan Opsi Kebijakan, Brief CIFOR.

Puspitojati T., Mile M. Y., Fauziah E., \& Darusman D. (2014). Hutan Rakyat Sumbangsih Masyarakat Pedesaan Untuk Hutan Tanaman. Yogyakarta: PT Kanisius.

Simon H. (2010). Dinamika Hutan Rakyat di Indonesia. Yogyakarta: Pustaka Pelajar.

Suprapto E. (2010). Hutan Rakyat: Aspek Produksi, Ekologi dan Kelembagaan. Jogjakarta: Lembaga Arupa.

Supriono A., Bowo C., Kosasih A. S., \& Herawati T. (2013). Strategi Penguatan Kapasitas Kelompok Tani Hutan Rakyat di Kabupaten Situbondo. Jurnal Penelitian Hutan Tanaman Vol. 10. No. 3,1139 - 146

Syahadat, E., \& Subarudi. (2014). Kajian Kebijakan Penatausahaan Kayu yang Berasal dari Hutan Hak. Jurnal Analisis Kebijakan Kehutanan, Vol. 11 No. 2.

Syarief A. (2012). Analisis Implementasi Kebijakan Sekolah Bertaraf Internasional di SMP Negeri 5 dan SMA Negeri 3 Bandung, Tesis tidak diterbitkan. Universitas Indonesia

Triana R. W. (2012). Pendekatan dan Teori - Teori Implementasi Kebijakan Publik,(Online).(http://rochyati-wt-fisip.web.unair.ac.id/artikel_detail-69584-Umum-.html, diakses 21 Maret 2016)

Utari A. D. (2012). Penerapan Strategi Hutan Rakyat Opsi Penyelamatan Kehancuran Hutan Negara. Yogyakarta: Cakrawala. 